\title{
Brexit: On the declining homogeneity of European elites - and on the importance of a domestic habitus in times of globalization ${ }^{1}$
}

\author{
Michael Hartmann (hartmann@ifs.tu-darmstadt.de) \\ Darmstadt University of Technology, Germany \\ Klarissa Lueg (Klarissa.lueg@uni-flensburg.de) \\ Flensburg University, Germany
}

"The British economic elite - contrary to common perceptions of a globalized powerful elite - was not capable, not even on the national level, to prevent a decision which, to this elite group, is of eminently outstanding relevance." (M. Hartmann)

In this interview, Michael Hartmann addresses three aspects related to the social phenomenon "Brexit": mass vs. elite; elite vs. elite; and implications for the theoretical perspective on Bourdieusian power structure research. First, Hartmann argues that frustration as to social democratic and socialist politics, combined with social decline, fostered pro-Brexit votes - as well as, on a broader European level, mainly right wing protest movements. Second, Hartmann argues that two ideal typical groups of elites in the UK, the political and the economic one, have become alienated from each other previous to the Brexit discussion. This is demonstrated by the economic elite not being able to prevent the Brexit referendum which, potentially, is damaging to British economy. Alienation between the two groups is tied to globalized and diverse life courses. Globalization, here, is responsible for lessening social similarities between managers and politicians. Hartmann concludes that, given this habitus alienation, even an otherwise powerful globalized economic elite cannot oppose a domestic political elite. Third, and finally, Hartmann conjectures that the habitus concept will remain of empirical importance despite globalizing careers.

Klarissa Lueg: You have pleaded, repeatedly, for more citizen participation in political decision making. Now, the Brexit referendum was an act of citizen participation. The result is: NO to the EU. This came as a shock to many citizens, to the younger and more educated ones, in particular. Right after announcement of the referendum outcome, desperate young people, in the UK, voiced anxiety about their future. There is little evidence of "the people" having profited from Brexit. Yet, would you interpret the referendum, in this light, as a blow against the elites?

Michael Hartmann: It was a voting, in this case more or less from the political Right, against the traditional elites - and those of the City of London in particular. Protest can be uttered in various ways. In the UK it was a movement of rightist populism, extending

\footnotetext{
${ }^{1}$ The interview was translated from the original German. All translations are layman translations, K.L.
} 
far into the Conservative Party. Rightist populism succeeded in focusing the protest movement. However, it should be said, the impression of the Old having outdone the Young, is not in line with reality. Just look at the voter turnout of the Young: the majority voted against Brexit, but turnout was miserable. Meaning, the majority of the younger generation didn't care. Meaning, again, those headlines - the Old outvoted the Young -, that's just not true. The Old out-voted those of the Young who went voting, and that was a minority. Also, what became evident in the UK: decisive, in the end, are the differences in real living conditions. According to a new study, on living conditions in Great Britain [from here: GB, K.L.], partly in relation to the Brexit, three quarters of regions, in terms of living standards, are below the European average level. Better-off regions are just London and the South East, and a few enclaves, such as Edinburgh, or Manchester. During the last 30 years, the North of England has experienced, simply, and in the best case, standstill, mostly, however, decline. This is what people reacted to. Older people voted Brexit, and younger people said we don't care. And that may be different only in places where, during the last 30 years, improvement is tangible.

Klarissa Lueg: The NO to EU slogan is often interpreted as not being directed against the EU, only and immediately, but also against elitist communication, perceived as downgrading, in general. There were, in parallel to the Brexit discussion, the TTIP and CETA discussions, largely behind closed doors. This way of "communicating": why is it being continued, in the face of direct protest demonstrations and of indirect protest by way of voting decisions of "the people"?

Michael Hartmann: To the EU Commission, it would have preferred - and this was common practice until now - to negotiate and conclude TTIP and CETA behind closed doors. This doesn't work any longer. Large portions of populations, obviously in Germany, intervened to a degree not expected by the traditional political elites. Popular intervention forces politics to open up procedures wider than planned. It is most convenient for political institutions and in particular for the elites in Brussels, to decide on things without much ado and then to sell such decisions, to the public, as political wisdom without alternative, as the inescapable opening of markets. For three decades now, politicians have declared globalization and its consequences to be without alternative; and people have accepted this for a long time. This is the easiest way of doing politics. You just say, that's the only way to be done, and you, the people, just have to accept it. As a kind of overwhelming natural law. However, this is not being accepted any longer. As to TTIP and CETA, people were afraid of governmental curtailing of democratic procedures as well as of ecological standards and labor and employment law. Of course, there were some few unsubstantiated fears. But, again, they were kindled by governments' secret diplomacy. Protest movements, in general, may develop both in a rightist or a leftist direction. A case in point is globalization criticism. However, as to protesting CETA and TTIP, that's criticism from the left.

Klarissa Lueg: You just mentioned that criticism of internationalization and globalization may be raised both from the leftist or rightist position. It has been said, by some, that repudiating the $E U$ was nourished by rejecting migration - a rejection not only of non-EU refugees but also of EU migrants. Right after the Brexit referendum, there was a sudden increase of xenophobic attacks and harassments, and minority-hostile rhetoric rose. Skepticism of elites co-incited, it seemed, with xenophobia and resistance to change. This led to feelings of being shocked and victimized, not only on the part of the young and educated but also of migrant people, marginalized as they were even before. Hence, here comes 
a question of ethical concern: "Power to the People" - is that always a good idea?

Michael Hartmann: First of all, you have to look at Southern Europe; Portugal, Spain, Greece - there, we don't have any of this. Look at Podemos, or Syriza before, or installing the new government in Portugal: protest movements, there, tended to develop in a leftist direction. This means that protesting the dominant line of politics does not necessarily imply a rightist impetus. That impetus, it is true, is at work in most countries and regions; look at France, Germany, the UK, Austria. In these countries, protest action often is connected to a deep-seated disappointment with political parties usually associated with the left. In France, people voted for the socialist Hollande who promised to pursue a political programme completely different from that of his predecessor Sarkozy. Hollande said: those close ties to business, the decrease of social benefits - all this will be reversed. Nothing happened, though; Hollande voters are disappointed, accordingly. In the UK there is disappointment with Blair and New Labour who, basically, followed the course of the Conservatives. In Germany it is disappointment with Social Democracy, clearly demonstrated, at the latest federal state elections, by AfD [Alternative für Deutschland, K.L.] voters. The newly established section of AfD voters - those without a stable rightist outlook, having voted AfD just for protest - is made up, predominantly, of former SPD voters. They want to teach the SPD [Sozialdemokratische Partei Deutschlands, K.L.] a lesson. In all of these countries people refuse to believe in promises - and in promises of Social Democrat/Socialist parties in particular. And, searching for alternatives, these people, at present, and unfortunately, tend to turn to the right. In this context, nationalism undergoes a revival, implying seclusion from the markets, xenophobia, and racism. This can be observed in France, quite well. There is this book, by Didier Eribon, in which he describes how his family, formerly faithful Communist Party voters, turned into Front National voters. It is decisive here that these people feel deserted, that the demise of a whole population of industrial workers, in the North East, has been accepted, more or less indifferently, by the elites of Paris, including those of the Socialist Party. Socialist are blamed, in the first place; and they are seen as representing the Left altogether, because the Communists formed part of the Mitterrand government. Also, we must consider that even in the old Communist Party there was racism, mainly during the Algerian War, but it was not perceived as such. The average French worker, though voting for the Communists, did not adhere to the Algerian liberation movement. They were against it. The Communist Party, however, could not openly endorse racist attitudes among its voters. Racism was not in line with the goals of Proletarian Internationalism, even if that ideology, partly, served as a facade only. The predominant feature of the French Communist Party was fighting capitalism. Today, with the Front National, objectives are in reverse order, exactly. The Front, in terms of social politics, does offer programs which clearly resemble former Socialist offers. Xenophobia, however, is dominant with the Front. It is at the core of their program.

Klarissa Lueg: Do you see a point of leverage, politically, for counter-acting this Rightist populism?

Michael Hartmann: Right, that would be, always, in the field of social politics, or labour market policy. To go ahead there you would have to take note, in the first place, of deteriorations having inflicted large parts of the population during the last decades. You would have to stop denying all of these deteriorations - as if globalization and European unification were, for all of us, a process of tangible success. No. Both, globalization and unification have brought real worsening of life conditions for many people. We must ask: why is this so? And what can we do to counter-act it? And then we got to act, according- 
ly. For Germany, this would mean repealing the Hartz laws, or changing the tax policy concerning high incomes and assets. That way, we would be able, most promisingly, to tackle the aversion to politics as well as Rightist populism.

Klarissa Lueg: I would like to talk about two elite groups who acted from contrary positions: the economic elite and the political elite. In terms of generalization, one might say that the political elite has stirred up and maintained sentiments hostile to the EU, whereas the economic elite has attempted to hold off such sentiments. Now, one must get the impression that the economic elite, in contrast to this special political elite, is relatively powerless?

Michael Hartmann: It is not two completely homogeneous elite groups facing each other. In the case of the economic elite, the anti-Brexit position has been, unequivocally, a majority position. It is true, there were some pro-Brexit voices in big business, but at its core the British economic elite was anti-Brexit. In the case of the political elite this was much less obvious. The ruling party, the Conservatives, was split up in a 50:50 situation. There were prominent anti-Brexit voices, and there were prominent pro-Brexit voices. At any rate, the economic elite, in contrast to earlier decades, was not in a position to commit a majority of the Conservative Party to the course the business elite wanted. Traditionally, in the UK, big business had been predominant. In political matters of massive economic concern, it had always been the City of London group of big business world market oriented and amenable to globalization - who made the final decisions. And the Conservative Party, usually, did accept and even support these decisions. Now, with Brexit, this constellation has not worked, for the first time since decades.

Klarissa Lueg: This new discrepancy: you explain it with reference to the habitus concept, in pointing to a decline of biographical similarities.

Michael Hartmann: The Conservative Party and the economic elite do not have so much in common as they used to. Up to the $90 \mathrm{~s}$, the relatively small group of graduates from the leading nine public schools, the Clarendon Nine, provided more than one quarter of big business top Managers, as well as every third cabinet member of conservative governments. Another inter-relational element was Oxbridge graduation. One of two top managers, and four out of five members of governments were Oxford or Cambridge graduates. Such common experiences, in the UK, have been diminished, exceedingly, through opening of markets and internationalization of business elites. Actually, the UK is one of the very few countries with an actual internationalization of the business elite. At least every third top manager is a foreigner and doesn't have a UK passport. By international comparison, this is an extremely high figure, surpassed only by Switzerland, and, beyond Europe, by Australia. This development works against the traditional mechanism of sharing common backgrounds. Foreigners graduated from foreign universities. Internationalization diminished the importance of traditional British institutions. In the old times, in cabinet sessions, one Etonian sat next to another Etonian. This was a homogeneous group which, under Thatcher, provided more than one fourth of cabinet members. In banking, even every second top manager was an Etonian. So, as long as filling top positions used to be a purely British affair, these traditional institutions, like Eton, were of considerable impetus. With increasing numbers of foreigners, at the top of big enterprises, this has changed. And connections between economic and political elites have been loosened, from year to year. As a consequence, the economic elite - contrary to perceptions of a globalized powerful elite - was not fit, not even on the national level, to pre- 
vent a decision, the Brexit, which to them is extremely important. Arguably, a large part of the finance elite must look out for new headquarters, as they are not able to serve, from London, the complete market of Euro loans etc. That would be a severe incision. They wanted to avoid that. However, ties to the political elite did not work sufficiently; the conservative party was split in two. And honestly, on the other hand, there were Brexit proponents in politics; I am talking primarily of Johnson, who did not really figure to be tangibly successful. Johnson played a game: who can recommend himself for the position of the future prime minister?

Klarissa Lueg: In terms of social theory, your work can be related to a Bourdieusian tradition, and quite prominent here are the habitus and the accumulation of capital. There are a number of researchers dealing with the question of how capital is transferable and internationally applicable. You yourself assume that, with elites falling apart due to internationalization, common experiences like attending common educational institutions will become less relevant. What does this mean for the habitus concept? When talking about international spaces, do we have to take leave of that concept, to some measure?

Michael Hartmann: The concept of habitus will stay extremely important. To begin with, we must recognize that the vast majority of top managers live and work in their home countries. This applies, even regarding the 1000 biggest and globally most active enterprises worldwide, to nine out of ten CEOs. In most countries, primarily the larger ones, like USA, China, India, or Japan, the number of such managers is even considerably higher. And even in countries having undergone an outright internationalization of economic elites changes are not always as far-reaching as one would assume. Social backgrounds of top managers have not changed trough internationalization, at least not in Great Britain. I check this, regularly, as far as data allow. And the foreigners who now are heading British enterprises are, as to social origin, not different from Britons. Originating from upperclass/upper middle class backgrounds is normality still. In the UK, there are, on a regular basis, studies by the Social Mobility and Child Poverty Commission. The last study is on recruiting practices of law and elite financial service firms and there, too, I encountered the classical pattern. These firms are searching for persons wo are „posh“ - meaning, usually, upper class origins and graduation from renowned schools - , persons, that is, having the right habitus. And this recruiting mechanism, it seems, is still relevant in the UK. It is true, the habitus, even in the UK, is constantly being re-shaped; its social groundwork, however, is much more stable than you would expect facing those many foreigners in leading positions. This supports assuming that, beyond national frontiers, there are personal characteristics allowing topmanagers to recognize each other. To me, then, the habitus concept remains the key for exploring procedures of recruiting and positioning, and for exploring elites in general. Even though, we must ask if and how the habitus, provided the international market development will continue its present way, will go along in developing and transforming itself. Let's look at Switzerland. There, the national habitus, distinctly definable in earlier days, clearly has lost relevance. The Swiss Habitus was shaped by membership in the officers' corps of the Swiss Army and by graduation from the ETH Zurich or the University of St. Gallen or the Bern Law School. Swiss Habitus has now become more diffuse - three out of four Swiss top managers originate from foreign countries. On the other hand, we cannot say, yet, that something like a new habitus is emerging. In politics and in the civil service the old habitus is still predominant. Not so in business. It can be questioned, though, whether the internationalization of top management will continue going ahead. Take the UK, again, as an example. Here, on CEO level, there was no trend to fill vacant positions with foreigners. On the contrary, we can observe a slight backward development; the foreigner proportion slightly decreased. I 
have found out the same for Germany. It may imply that the trend to internationalization, as concerning the business elite, has been halted - in the UK with a proportion of a third of CEOs being foreigners, in Germany with nearly $15 \%$. These are, in international comparison, very high figures. In most countries, percentages are much lower. That is to say, in most countries nationally defined types of habitus are still valid, quite obviously, and are still dominant even in Germany or the UK.

Klarissa Lueg: In some fields already, internationality or cosmopolitism, including English as a lingua franca, functions as symbolic capital, at the university, for instance. For one thing, English as common language in higher education is being accepted, more and more; and also, in job postings, international qualifications are asked for, in growing measure.

Michael Hartmann: But even there, the necessary habitus is characterized by national culture and practices, and much stronger than usually assumed. You will find this out only in researching it in detail. At first glance, you will notice that even for filling post-doc positions applicants are often expected to have spent at least one year at a top university abroad. In procedures relating to the appointment of professors there is often reference to publications in English-language journals with high impact factors, and to research projects abroad. „Abroad“ meaning, in general, the USA or the UK. If, however, you look at the power positions in academia, the secretaries general or the presidential committees, like those of DFG, MPI or HRK in Germany, you will notice - and this has been researched by Angela Graf only recently - that not much is left of this trend for internationalization. There, nationally oriented careers are clearly predominant; these people, in order to get hold of these power positions, must be active in national networks.

\section{References}

Social Mobility and Child Poverty Commission (2015): A qualitative Evaluation of noneducational barriers to the elite professions. London

Erel, Umut (2010): Migrating Cultural Capital. Bourdieu in Migration Studies. In: Sociology, 44, Heft 4, S. 642-660.

Eribon, Didier (2016): Rückkehr nach Reims. Suhrkamp: Berlin.

Graf, Angela (2016): Eliten im wissenschaftlichen Feld Deutschlands - Sozialprofil und Werdegänge. In: Soziale Welt, 67, Heft 1, S. 23-42.

Hartmann, Michael (2007): Eliten und Macht in Europa. Campus: Frankfurt am Main.

Hartmann, Michael (2016): Die globale Wirtschaftselite. Eine Legende. Campus: Frankfurt am Main.

Igarashi, Hiroki/Saito, Hiro (2014): Cosmopolitanism as Cultural Capital: Exploring the Intersection of Globalization, Education and Stratification: Cultural Sociology, 8, Heft 3, S. 222-239.

Lueg, Klarissa/Lueg, Rainer (2015): Why do students choose English as a medium of instruction? A Bourdieusian perspective on the study strategies of non-native English 
speakers. In: Academy of Management Learning and Education, 14, Heft 1, S. 5-30.

Prieur, Annick/Savage, Mike (2011): Updating cultural capital theory. A discussion based on studies in Denmark and in Britain. In: Poetics, 39, Heft 6, S. 566-580.

Weenink, Don (2008): Cosmopolitanism as a Form of Capital: Parents Preparing their Children for a Globalizing World: Sociology, 42, Heft 6, S. 1089-1106. 